\title{
Vibratory Stress Relief and Vibratory Weld Conditioning of Flux cored arc welded CA6NM steel
}

\author{
Luiz Fernando Cursino Briet de Almeida ${ }^{1}$, Julio César Lourenço ${ }^{1}$, Maria Ismênia Sodero Toledo Faria ${ }^{1}$, Décio \\ Lima Vieira ${ }^{2}$, Alain Laurent Marie Robin ${ }^{1} \&$ Carlos Ângelo Nunes ${ }^{1}$ \\ ${ }^{1}$ Universidade de São Paulo (USP) - Escola de Engenharia de Lorena, Lorena, São Paulo, Brazil \\ ${ }^{2}$ ALSTOM Brasil Energia e Transporte LTDA, Taubaté, São Paulo, Brazil \\ Correspondence: Julio César Lourenço, Universidade de São Paulo (USP) - Escola de Engenharia de Lorena, \\ Lorena, São Paulo, Brazil. E-mail: julio.lourenco@usp.br
}

Received: November 19, 2019

Accepted: December 13, 2019

Online Published: December 31, 2019

doi:10.5539/jmsr.v9n1p32

URL: https://doi.org/10.5539/jmsr.v9n1p32

\begin{abstract}
ASTM A743 CA6NM steel is used in the manufacturing of hydraulic turbines components. Multipass welding is commonly used for their fabrication or repairing. In this work, two different vibratory welding procedures were studied: vibration applied during welding (VWC) and vibration applied after welding (VSR). Results have shown that in both conditions, CA6NM steel presented a martensitic microstructure, in which the VSR welded joint presented column-shaped packets and fine martensite delineating the individual beads, while VWC joint presented grain refinement. Heat affected zones (HAZ) presented $\delta$-phase in small amounts for both conditions in the regions which reached higher temperatures. VSR and VWC conditions presented similar behavior in terms of hardness, HAZ hardness values being close to those of the weld metal, except for the root regions, where higher values were obtained. Charpy-V results showed that HAZs presented higher impact values than those of the weld metal. The low impact values of the weld metal were attributed to presence of inclusions from the welding electrode.
\end{abstract}

Keywords: Martensitic CA6NM stainless steel, Welded joints, Flux cored arc welding, Vibratory weld conditioning, Vibratory stress relief, Post weld heat treatment

\section{Introduction}

The Brazilian energy matrix is based on the use of electricity generated by hydroelectric plants, which use different types of hydraulic turbines. The main processes used to manufacture several components of these turbines are casting and welding (de Gouveia, Marenda Pukasiewicz, Capra, Henke, \& Okimoto, 2013; Gouveia, 2008). The martensitic CA6NM stainless steel is generally used to manufacture rotor and blades of these turbines due to its increased resistance against corrosion and cavitation damage, combined with high mechanical strength and good weldability (Akhtar \& Brodie, 1979; Folkhard, 1988). Nevertheless, hydraulic turbines can present several problems, cavitation erosion and cracking in high stress concentration regions being responsible for the major damage. These defects are repaired by welding process (Prado, 2004; Pukasiewicz, 2008).

After either welding of the parts or repairs, a post weld heat treatment (PWHT) is normally applied, because martensitic stainless steels have a tendency to form a hard and brittle martensite structure in the heat affected zone (HAZ) as well as in the weld metal (WM). It makes difficult to weld successfully without formation of cold cracks during cooling. The reduction in toughness combined with high levels of residual stress can decrease the component service lifetime (Thibault, Bocher, \& Thomas, 2009). Heat treatment is the most traditional method to relieve residual stresses, however, it is often limited by manufacturing conditions and by the size of the structures (Nguyen \& Wahab, 1996). In addition, it is also difficult to be carried out for on site repairs. To solve these problems, many studies have been conducted to find alternatives and new procedures for welding processes (Jurcius, Valiulis, \& Cernasejus, 2010; Robbins, 2004; Wu, 2000; Wu, Lin, \& Chen, 1999).

Kainth \& Gupta (2015) have carried out a review concerning the effect of vibrations on mechanical properties of welded joints. Authors presented results from 24 articles, mainly about steels. In conclusion, they inform that vibration during welding greatly benefits grain structure due to dendrite fragmentation and detachment as well as the total cooling rate. These are the two major factors that contribute to the enhancement (refinement) of grain 
size of vibrated microstructures, leading to better mechanical properties. In addition, vibration may also aid to produce weld joints of lower residual stresses as has been demonstrated in a recent article from Ingram et al (2019). Authors inform that vibrating structures while welding can, in some cases, contribute to stress relief by means of small deformations induced by the structural vibration, because the locally heated joints (with their substantially lower yield strength) experience stresses that exceed the yield strength. This procedure, however, is strongly dependent on the structure's geometry and frequency response.

The welding process used in this work was the Flux Cored Arc Welding (FCAW), typically applied for larger thickness parts where the geometry of the joint and the welding position do not allow the application of weld process with high deposition rate such as submerged arc or electroslag welding, which is the case of some components of the hydraulic turbines (Moraes Junior, 2013). FCAW is an arc welding process that uses a tubular wire filled with a flux. The aim of this investigation was to analyze the effects of applying mechanical vibration during and after FCAW welding process of martensitic CA6NM stainless steel on its mechanical properties and to make a comparison with the conventional method in terms of microstructure and mechanical properties. Results for the as-welded (no vibration) as well as post weld heat treated (PWHT) joints were published previously (Silva et al., 2017).

\section{Experimental Procedure}

For the present study, two CA6NM steel plates from the same batch were supplied by Electro Aços Altona S.A. The CA6NM steel was melted in a conventional arc furnace, refined in an Argon Oxygen Decarburization (AOD) furnace and cast in 300x400x45 mm sand molds. Subsequent quenching and tempering were applied to produce the mechanical properties to the standard requirements. Table 1 shows the chemical composition of the CA6NM steel according to the ASTM A743/A743M standard as well as the chemical composition of the AWS E410NiMoT1-4/-1 (Silva et al., 2017) tubular wire (welding electrode), with $1.6 \mathrm{~mm}$ diameter, manufactured by Mckay Company attending to ASME/AWS SFA 5-22 specifications (AWS, 2012).

Table 1. Chemical compositions (wt.\%) of CA6NM steel according to ASTM A 743 / A743M standard and AWS E410NiMoT1-4/-1 electrode.

\begin{tabular}{lllllllll}
\hline Element & C & Mn & Si & Cr & Ni & Mo & P & Cu \\
\hline $\begin{array}{l}\text { ASTM A 743 } \\
\text { CA6NM }\end{array}$ & 0.06 & 1.0 & 1.0 & 11.5 & 3.5 & 0.4 & 0.04 & 0.00 \\
\hline AWS E410NiMoT1-4/-1 & & & & 14.0 & 4.5 & 1.0 & & \\
\hline
\end{tabular}

Table 2 compares the mechanical properties of CA6NM steel used in this work to the requirements found in ASTM A743/A743M standard. Table 3 presents the mechanical properties specifications of weld filler metal AWS E410NiMoT1-4/-1 electrode (ASME/AWS SFA5.22, 2012) (AWS, 2012).

Table 2. Mechanical properties of CA6NM steel according to ASTM A743/A743M standard and corresponding values for the steel used in this work.

\begin{tabular}{lll}
\hline Mechanical Properties & ASTM A 743/ A 743M (1998) & Steel used in this work \\
\hline Ultimate tensile strength (MPa) & $755(\mathrm{~min})$ & 795 \\
Yield strength (MPa) & $550(\mathrm{~min})$ & 684 \\
Elongation, in 2 inches (\%) & $15(\mathrm{~min})$ & 22 \\
Area reduction (\%) & $35(\mathrm{~min})$ & 65 \\
Hardness (HB) & $285(\max )$ & $269-277$ \\
\hline
\end{tabular}

Table 3. Specifications of mechanical properties for final welded parts using AWS E410NiMoT1-4/-1 welding consumable electrode.

\begin{tabular}{ll}
\hline Mechanical Properties & Found weld metal properties \\
\hline Ultimate tensile strength (MPa) & 917 \\
Yield strength (MPa) & 848 \\
Elongation (\%) & 17 \\
Radiographic exam & In accordance \\
Hardness (HB, average) & 253 \\
Impact energy Charpy-V (average) & $46 \mathrm{~J}$ at $-18^{\circ} \mathrm{C}$ \\
\hline
\end{tabular}


Four samples of 97x300x45 mm dimensions were cut from the recieved plates of CA6NM steel and were mill machined to obtain two X beveled edges, as the one shown in Figure 1. Each X beveled edges were pre-heated at $100{ }^{\circ} \mathrm{C}$ for $45 \mathrm{~min}$ before welding to reduce the cooling rate and avoid the appearance of cracks, in addition to decreasing internal stresses after welding. The $\mathrm{X}$ beveled edges were welded according to a WPS qualified according to ASME IX 2013 standard (ASME, 2013) by FCAW (Flux Cored Arc Welding).

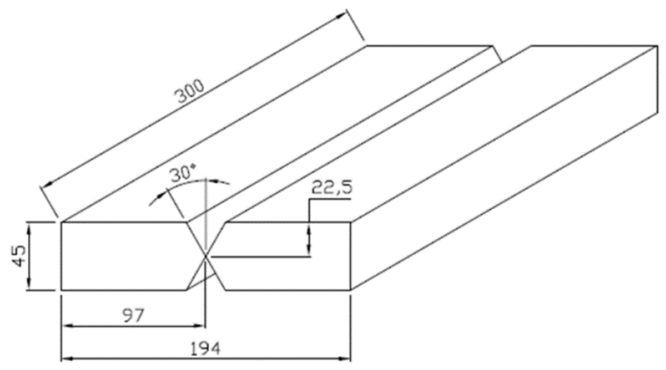

Figure 1. Schematic drawing of $\mathrm{X}$ beveled CA6NM steel samples (dimensions in $\mathrm{mm}$ )

Table 4 presents the welding parameters used for the joints produced in this work. The following welded joints were produced and characterized: i) joint $\# 1$ - vibration applied during each welding pass (Vibratory Weld Conditioning - VWC code); ii) joint \#2 - vibration applied immediately at the end of the welding process (Vibratory Stress Relief - VSR code). After welding all the joints were kept at at $200{ }^{\circ} \mathrm{C}$ for $30 \mathrm{~min}$ and a low cooling rate was assured using a thermal blanket. Non-Destructive Tests (NDT) by radiography were used to ensure the integrity of the welded joints. Joints for the condition as-welded, no vibration (AW code) and post weld heat treated (PWHT code) were produced similarly and the results published elsewhere (Silva et al., 2017). The results of the AW and PWHT joints are included here to facilitate comparisons.

Figure 2 presents a schematic view of one welded joint, indicating the sequence of weld passes applied. For the $\mathrm{B}$ side a ceramic backing welded in $3 \mathrm{G}$ ascendant position was used for all joints. The interpass temperature was maintained under control around $200^{\circ} \mathrm{C}$.

Table 4. Parameters and conditions used to produce welded CA6NM samples.

\begin{tabular}{ll}
\hline Consumable & Flux cored wire of $1.6 \mathrm{~mm}$ diameter \\
Current & $215-235 \mathrm{~A}$ \\
Voltage & $24-26 \mathrm{~V}$ \\
Welding speed & $9 \mathrm{~cm} / \mathrm{min}$ (root) $-18 \mathrm{~cm} / \mathrm{min}$ (surface) \\
Heat input & $35 \mathrm{~kJ} / \mathrm{cm}$ (root) $19 \mathrm{~kJ} / \mathrm{cm}$ (surface) \\
Protection gas & $75 \%$ Argon $+25 \% \mathrm{CO}_{2}$ \\
Shield gas flow rate & $20 \mathrm{~L} / \mathrm{min}$ \\
\hline
\end{tabular}

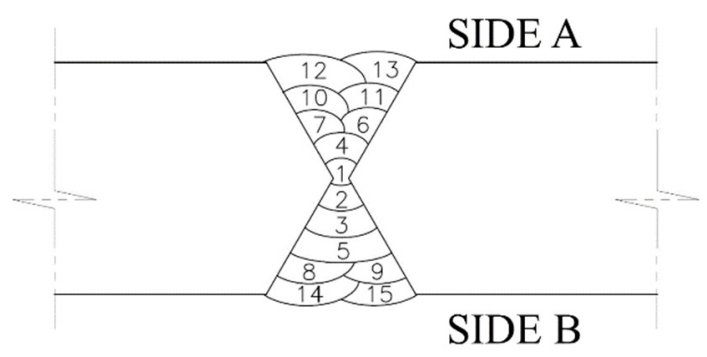

Figure 2. Welding sequence used in the samples.

For macroscopic imaging, samples from the joints were prepared according to ASME IX, QW 470 and QW 471 standards (ASME, 2013). For the metallographic characterization Villela's reagent and was also used for the 
specimen for comparisons purpose. Scanning electron microscopy (SEM) and Energy-Dispersive Spectroscopy analysis (EDS) were also used for microstructural characterization.

In order to determine the constituent phases, $\mathrm{X}$ ray diffraction (XRD) experiments were performed employing $\mathrm{Cu}-\mathrm{K} \alpha$ as well as $\mathrm{Mo}-\mathrm{K} \alpha$ radiations. The following conditions were adopted: $\mathrm{Cu}-\mathrm{K} \alpha-2 \theta$ in the $10^{\circ}-120^{\circ}$ range; $0.02^{\circ}$ step; counting time of $20 \mathrm{~s}$; Mo-K $\alpha-2 \theta$ in the $10^{\circ}-80^{\circ}$ range; $0.05^{\circ}$ step and counting time of $2 \mathrm{~s}$.

Tensile, Vickers hardness measurements and Charpy-V impact tests were performed in accordance with ASTM A370 (ASTM, 1997) and ASME IX standards (ASME, 2013). For the hardness measurements a load of 500 gf was applied for $30 \mathrm{~s}$. Figure 3 shows schematically the points where the hardness identations were performed. Charpy tests were carried out at $-20^{\circ} \mathrm{C}$, in triplicate, according to ASTM A370 (ASTM, 1997), V notch, type A. The Charpy samples were removed from the joints according to ASME VIII div 1 §UG 84 standard (ASME, 2013) and identified as S (3/4 of the thickness, in the weld metal); SS (1.5 mm from the surface, in the weld metal), HAZ1 (between 1/2 and 1/4 of the thickness at the left side of the HAZ); and HAZ2 (between 1/2 and 1/4 at the right side of HAZ).

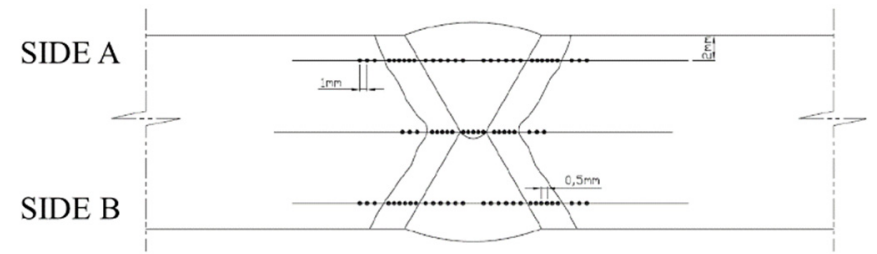

Figure 3. Points of the welded section where hardness measurements were performed.

\section{Results}

Figure 4 (a1;b1) shows the macrostructure of multipass welded joints produced in this work: VSR (Fig. 4a1) and VWC (Fig. 4b1). The welded joints have shown structural integrity. For the VSR joint, each bead presented column-shaped packets microstructure and fine martensite delineating the individual beads. These columns follow the heat flow direction toward the surface of each bead (Amrei et al., 2016). The VWC joint shows a different microstructure, produced due to vibration during welding. The VWC joint has shown grain refinement, which should be caused by the increase in the nucleation rate as well as dendrite breaking associated with vibration during welding, preventing the formation of the column-shaped microstructure (Shankar, 1982).

It is better illustrated in Figs $4 \mathrm{a} 2$ and $4 \mathrm{~b} 2$ which show, respectively, OM micrographies from the weld metal of the VSR (Fig. 4a2) and VWC (Fig. 4b2) joints.

Figure 5 presents the X-ray diffractograms from the weld metal of the VSR (Fig 5a) and VWC (Fig 5b) joint as well as those of PWHT (Fig 5c) and AW (Fig 5d) conditions for comparison. The results suggest a single-phase martensitic microstructure for all joints, except for the PWHT joint which presented near $10 \%$ retained austenite (Silva et al., 2017) in addition to martensite. The reason for retained austenite in the weld metal of the PWHT joint should be related to different austenite initial composition when this material is reheated at $580{ }^{\circ} \mathrm{C}$ in the $\alpha$ $+\gamma$ two-phase field. The different austenite composition should be associated with lower $\mathrm{M}_{\mathrm{f}}$ temperature compared to that of the global alloy composition $\left(\mathrm{M}_{\mathrm{f}} \sim 100^{\circ} \mathrm{C}\right)$. According to Bilmes (Bilmes, Solari, \& Llorente, 2001), the heat treatment after welding promotes the martensite tempering and austenite precipitation, that remains retained under metastable state and finely distributed at the primary austenitic grain boundaries and at the martensite slatted grain boundaries. The retained austenite can lead to the improvement of mechanical properties, such as toughness.

Figure 6 presents the predominantely martensitic microstructure of different regions inside the heat affect zone (HAZ) of the VSR joint using OM, identical results being observed for the HAZ of the VWC joint. The region 1 of the HAZ (HAZ-1) (Figure 6b) has a coarser grain structure due to higher temperatures experienced during welding, with some $\delta$-phase residual observed predominately between prior austenite grain boundaries. With the analysis via OM and SEM it was not possible to detect the presence of reversed austenite in the HAZ, neither in the VSR nor in the VWC joint. Region 2 of the HAZ (HAZ-2) (Figure 6c) presents a finer grain structure due to the lower temperatures reached during welding. 


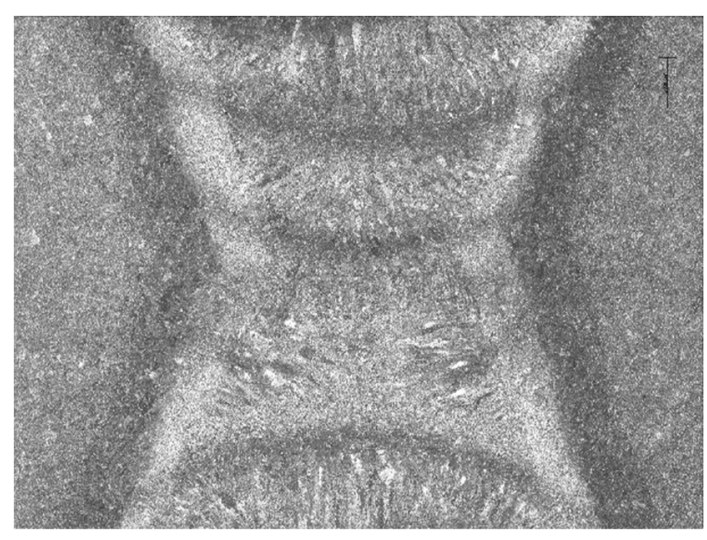

(a1) VSR - macrostructure

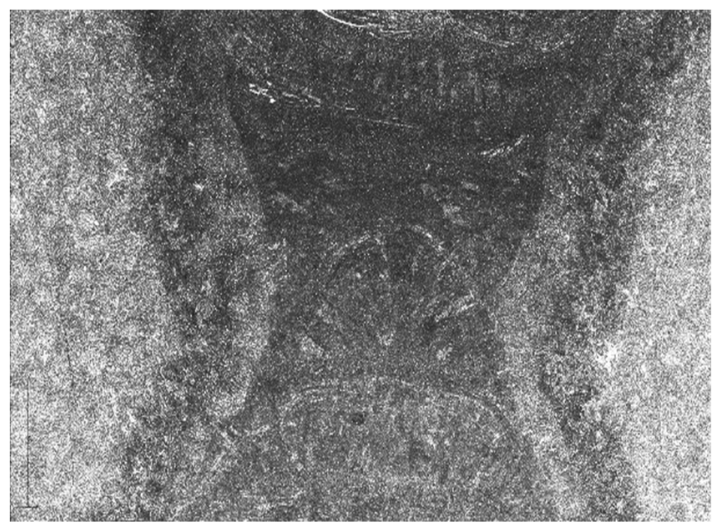

(b1) VWC - macrostructure

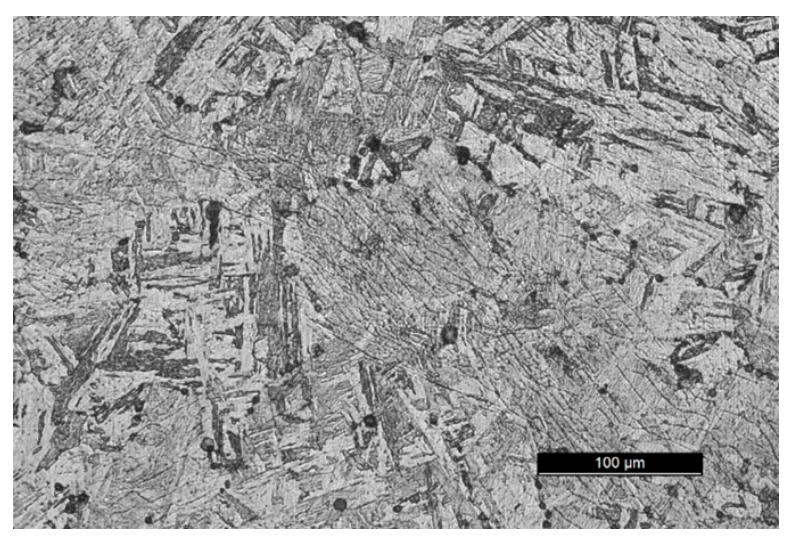

(a2) VSR - microstructure

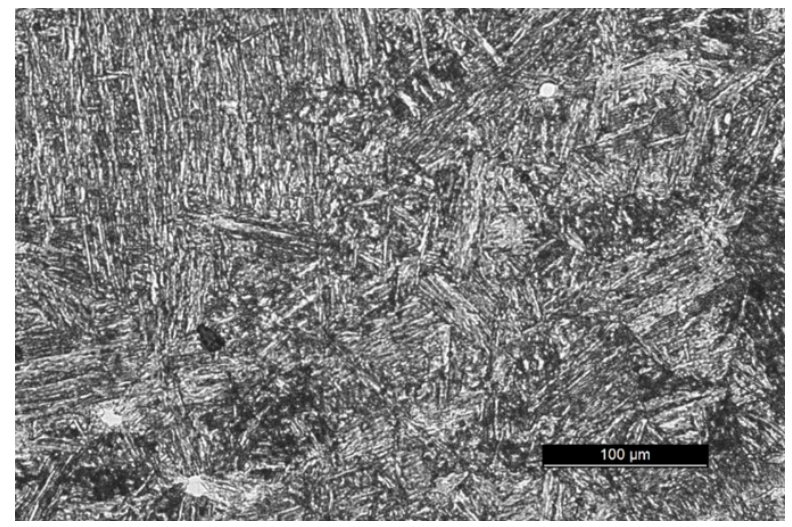

(b2) VWC - microstructure

Figure 4: Macrostructure and microstructure of multipass welding as a function of the welding procedure used VSR (4a1 - macrostructure; 4a2 - microstructure) and VWC (4b1 - macrostrucutre; 4b2 - microstructure). Microstructure shown for weld metal region.

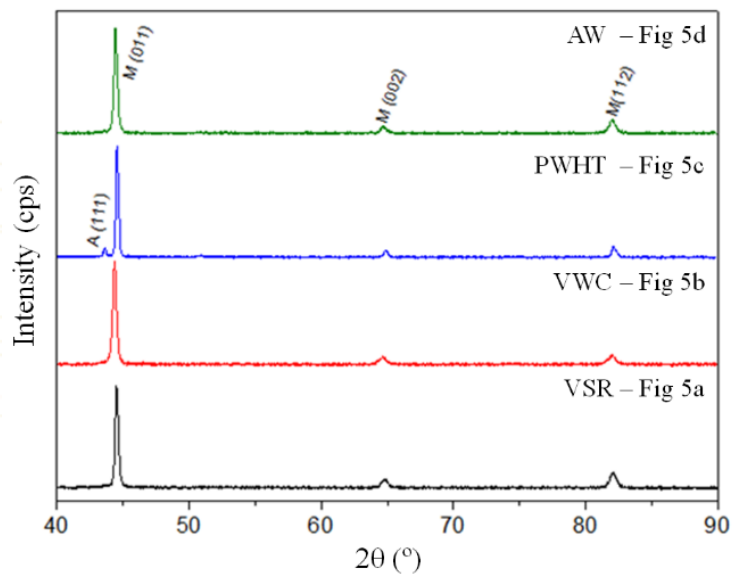

Figure 5. X-ray diffractograms of samples produced by the different welding procedures. (M: martensite; A: austenite). AW and PWHT conditions are published in Silva et al (2017). 


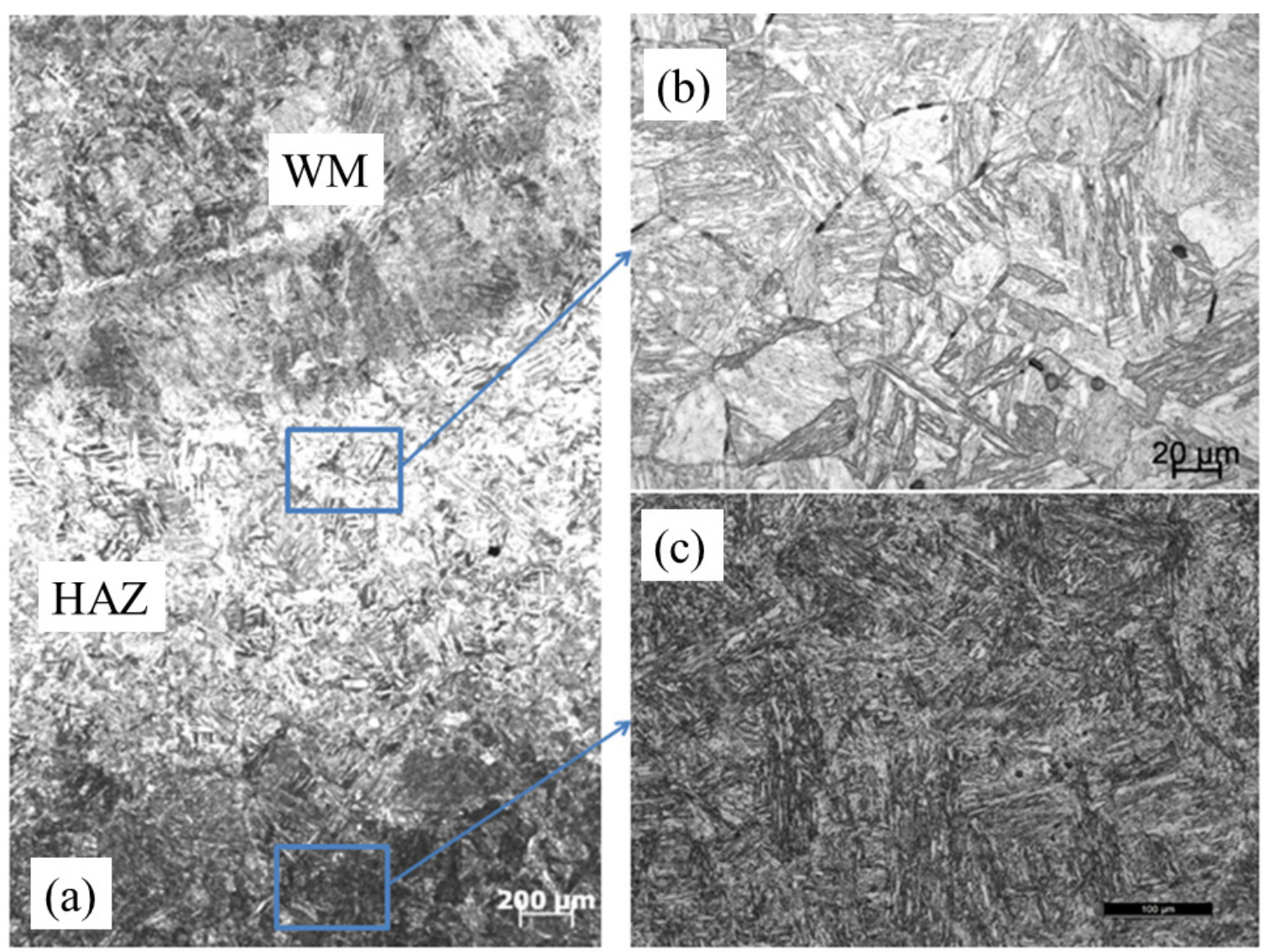

Figure 6. HAZ microstructure for the region in the top of the welding for the VSR condition. (a) is an OM mosaic image, (b) HAZ-1 (c) HAZ-2

Figure 7 shows the hardness values of VSR and VWC joints as well as those of the PWHT and AW joints for comparisons according to the measurements indicated in Figure 3. In general, the hardness increases from the base metal to the weld metal for all joints. Hardness values of HAZ regions are close to those of the weld metal, except for the root region (Fig. 7b) of the VWC and $\mathrm{AW}$ joints, where the weld metal presented higher values than those of the HAZ regions. The PWHT condition led to the lowest hardness values in the weld metal and HAZ compared to the other conditions, which could be attributed to the presence of retained austenite as well as tempered martensite in the PWHT joint.

Figure 8 shows the Charpy test values associated with the samples described in item 2. Results for the samples with notches located in the HAZ present, in general, significantly higher values than those of the weld metal. This could be, at least in part, associated to a contribution from the base metal (absorbed energy $\sim 97 \mathrm{~J}$ ) in these results, assuming that the crack propagation path may include the base metal. The VWC and VSR samples present near identical absorbed impact energy values for both S and SS notch regions, located in the weld metal, in addition, very similar results were also found for the AW and PWHT samples (Silva et al., 2017). 


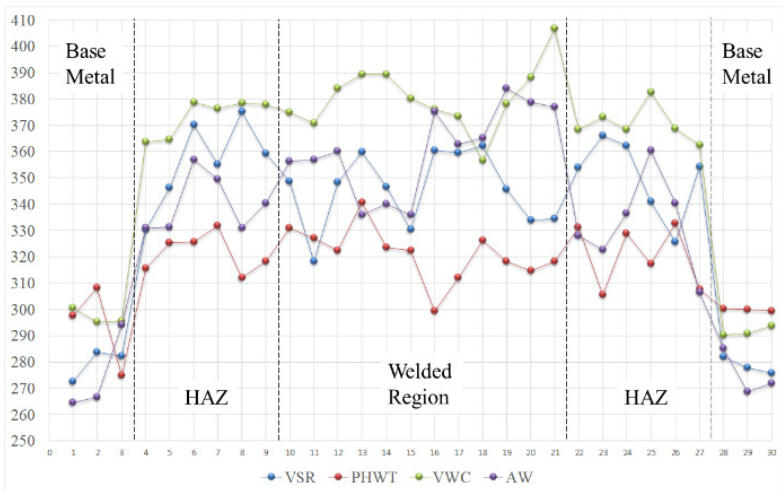

(a) Side A region

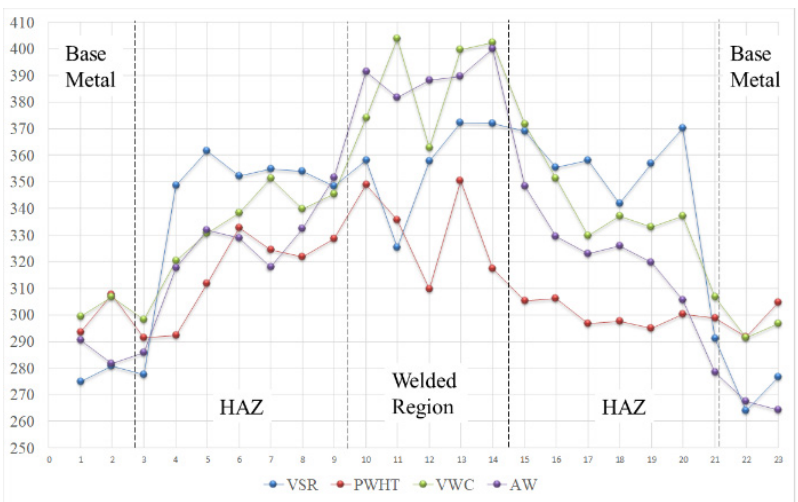

(b) Root region

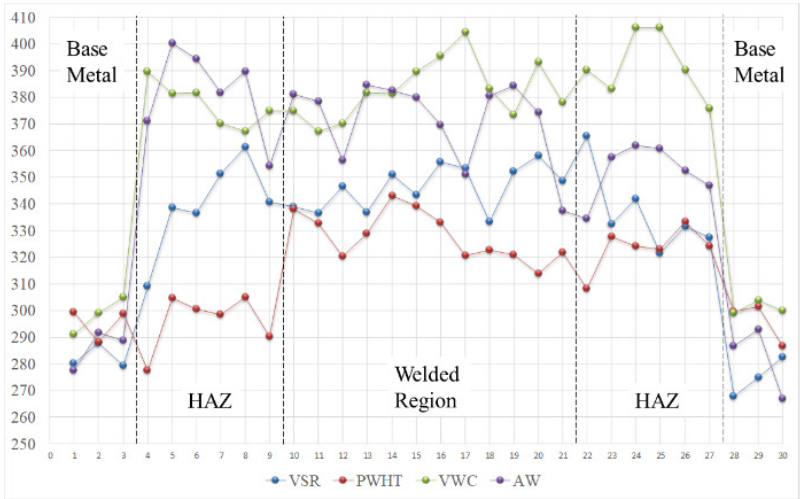

(c) Side B region

Figure 7. Microhardness profile for all conditions. AW and PWHT conditions are published in Silva et al. (2017)

It is proposed that the reason for these identical results should be associated with the presence of non-metallic inclusions (up to 100 microns) from the flux of welding electrode in all the joints, as exemplified in Figure 9. It should be noted that the welding standard specification ASME VIII MANDATORY APPENDIX 4 (ASME, 2004) accepts inclusions and cavities up to $6 \mathrm{~mm}$ in the welded joints. Due to these inclusions, energy values as low as $27 \mathrm{~J}$ have been obtained. However, no requirement about impact absorbed energy is mandatory for CA6NM steel, according to ASTM A743 standard (ASTM, 1998), the alloy supplier stipulates a minimum impact energy of $27 \mathrm{~J}$ for all notch regions. 


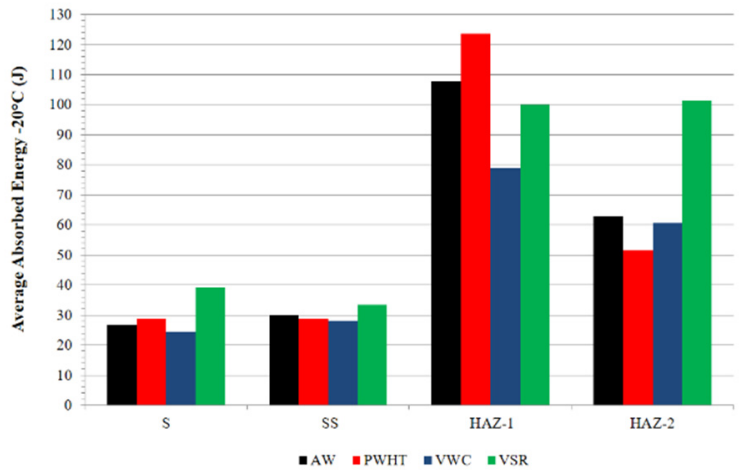

Figure 8. Average absorbed energy during Charpy- $\mathrm{V}$ tests for all samples and at different regions of the welded material. The tests were performed at $-20^{\circ} \mathrm{C}$. AW and PWHT values are published in Silva et al. (2017)

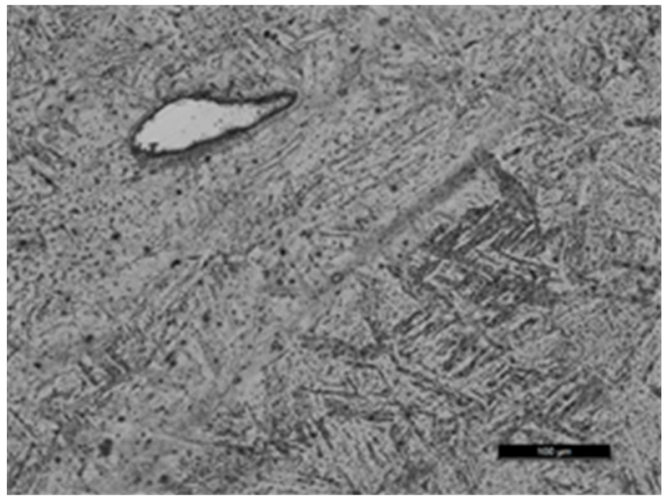

(a) VSR

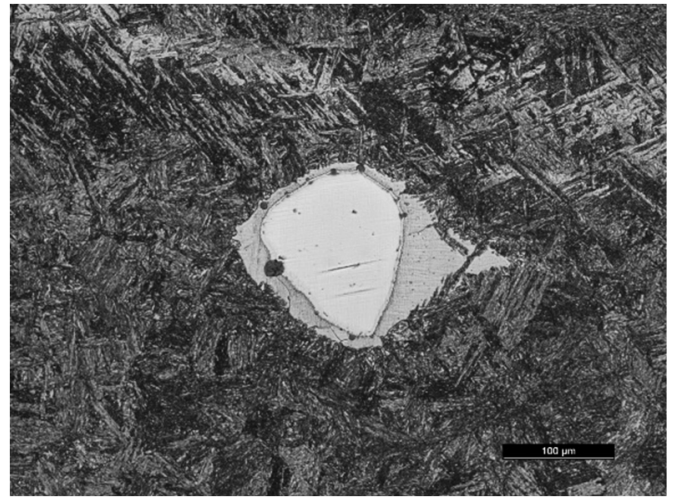

(b) VWC

Figure 9. Weld metal from VSR condition (Fig. 9a) and VWC condition (Fig 9b.) with inclusions from the welding electrode

\section{Conclusions}

In this work, mechanical vibration has been applied to evaluate microstructural changes in the welded CA6NM steel joints under two different conditions: vibration applied during welding (VWC condition) and vibration applied immediately at the end of the welding process (VSR condition).

VSR joint presented column-shaped packets and fine martensite delimitating the individual beads, while VWC joint showed grain refinement, attributed to the increase in the nucleation rate, as well as dendrite breaking associated to vibration during the welding procedure. From XRD measurements of the weld metal, VSR and VWC presented no retained austenite, suggesting only a predominantely martensitic microstructure.

The HAZs of both VSR and VWC joints presented $\delta$-phase in small amounts and no reversed austenite was present in the region that reached higher temperatures during welding procedure.

Both VSR and VWC joints presented an increase in the hardness values from the base metal to the weld metal, with HAZ regions presenting values closer to weld metal; except for the root region that presented higher values.

HAZ impact values were higher than those of the weld metal. The low impact values of the weld metal was attributed to the presence of the typical non-metalic inclusions from the fluxed welding electrode. As the size of the inclusions are acceptable for standards but conducted to low impact results, further studies must be carried out to improve the electrode material to reduce the amount of inclusion present the welded joints. Nevertheless, all impact values are in accordance with standards' requirements. 
In addition, in order to fully verify the advantages of applying VSR and VWC processes in the weld of CA6NM steels, further studies should also evaluate the residual stresses levels of the welded joints compared to conventionally welded joints and the feedback of experience demonstrates that the impact toughness achieved is enough for the hydro turbine need.

\section{Acknowledgements}

This study was financed in part by the Coordenação de Aperfeiçoamento de Pessoal de Nível Superior - Brasil (CAPES) - Finance Code 001.

\section{References}

Akhtar, A., \& Brodie, N. W. (1979). Field welding large turbine runners. Water Power \& Dam Construction, $40-46$.

Amrei, M. M., Monajati, H., Thibault, D., Verreman, Y., Germain, L., \& Bocher, P. (2016). Microstructure characterization and hardness distribution of $13 \mathrm{Cr} 4 \mathrm{Ni}$ multipass weld metal. Materials Characterization, 111, 128-136. doi:10.1016/j.matchar.2015.11.022

ASME, A. S. o. M. E. (2004). Boiler \& Pressure Vessel Code. In Section VIII DIV. I.

ASME, A. S. o. M. E. (2013). ASME IX. In Qualification standard of welding, brazing and fusing procedures; Wekders; Brazers; and welding, brazing, and fusing operators.

ASTM, A. S. f. T. a. M. (1997). ASTM A370. In Mechanical testing of steel products.

ASTM, A. S. f. T. a. M. (1998). ASTM A743/A743M-98a. In Standard specification for castings, Iron-Chromium, Iron-Chromium-Nickel, Corrosion resistant, for general application.

AWS, A. W. S. (2012). AWS A5.22/A5.22M: Specification for Stainless Steel Flux Cored and Metal Cored Welding Electrodes and Rods. In (pp. 68).

Bilmes, P. D., Solari, M., \& Llorente, C. L. (2001). Characteristics and effects of austenite resulting from tempering of 13Cr-NiMo martensitic steel weld metals. Materials Characterization, 46(4), 285-296. doi:10.1016/s1044-5803(00)00099-1

de Gouveia, R. R., Marenda Pukasiewicz, A. G., Capra, A. R., Henke, S. L., \& Okimoto, P. C. (2013). Interpass temperature influence on the microstructure, impact toughness and fatigue crack propagation in ASTM A743-CA6NM GTAW welded joints. Soldagem \& Inspecao, 18(2), 127-136. doi:10.1590/s0104-92242013000200006

Folkhard, E. (1988). Welding Metallurgy of Stainless Steels (1 ed.): Springer-Verlag Wien.

Gouveia, R. R. d. (2008). A influência da temperatura de interpasse na tenacidade do metal de solda na soldagem multipasse do aço inoxidável martensitico CA6NM pelo processo TIC. (Masters Degree), Universidade Federal do Paraná, Curitiba, Brazil.

Jurcius, A., Valiulis, A. V., \& Cernasejus, O. (2010). Effects of Vibration energy Input on Stress Concentration in Weld and Heat-affected Zone of S355J2 steel. Mechatronic Systems and Materials: Materials Production Technologies, 165, 73-78. doi:10.4028/www.scientific.net/SSP.165.73

Moraes Junior, J. M. (2013). Influência do tratamento térmico de alivio de tensões pós-soldagem na microestrutura e comportamento mecânico de soldas produzidas com arame tubular rutílico. (Masters degree), Universidade de São Paulo, Lorena, Brazil.

Nguyen, T. N., \& Wahab, M. A. (1996). The effect of residual stresses on fatigue of butt joints. Welding Journal, 75(2), S55-S61.

Prado, E. M. D. (2004). Influencia das variáveis do processo MIG/MAG convencional e MIG pulsado nas propriedades mecânicas de juntas soldadas com arame ER410NiMo. (Master's degree dissertation), Universidade Federal do Paraná, Curitiba, Brazil.

Pukasiewicz, A. G. M. (2008). Desenvolvimento de revestimentos Fe-Mn-Cr-Si-Ni resistentes à cavitação depositadas por aspersão ASP. (Doctor's thesis), Universidade Federal do Paraná, Curitiba, Brazil.

Robbins, M. E. (2004). Topics in Vibratory Stress Relief of Weldments. (Master of Science), Rensselaer at Hartford, Hartford, Connecticut.

Shankar, S. (1982). Vibratory stress relief of mild steel weldments. ( $\mathrm{PhD}$ thesis), Oregon Graduate Center, 
Silva, R., Almeida, L. F. C. B. d., Faria, M. I. S. T., Nunes, C. A., Vieira, D., \& Júnior, W. B. (2017). Microstructure and Mechanical Properties of ASTM A743 Steel Welded by FCAW Process. Materials Research. doi:10.1590/1980-5373-mr-2017-0468

Thibault, D., Bocher, P., \& Thomas, M. (2009). Residual stress and microstructure in welds of $13 \% \mathrm{Cr}-4 \% \mathrm{Ni}$ martensitic stainless steel. Journal of Materials Processing Technology, 209(4), 2195-2202. doi:10.1016/j.jmatprotec.2008.05.005

Wu, W. T. (2000). Influence of vibration frequency on solidification of weldments. Scripta Materialia, 42(7), 661-665. doi:10.1016/s1359-6462(99)00416-9

Wu, W. T., Lin, D. Y., \& Chen, S. H. (1999). Mechanical properties of weldment affected by various vibration frequencies. Journal of Materials Science Letters, 18(22), 1829-1831. doi:10.1023/a:1006647222302

\section{Copyrights}

Copyright for this article is retained by the author(s), with first publication rights granted to the journal.

This is an open-access article distributed under the terms and conditions of the Creative Commons Attribution license (http://creativecommons.org/licenses/by/4.0/). 